\title{
MEASURING SUSTAINABLE VALUE ADDED IN THE SCOPE OF ENVIRONMENTAL PERFORMANCE: AN APPLICATION ON BIST SUSTAINABILITY INDEX COMPANIES*
}

\author{
Dr. Öğr. Üyesi Onur ÖZEVINN**
}

Araştırma Makalesi / Research Article

Muhasebe Bilim Dünyası Dergisi

Aralık 2021, 23(4), 711-732

\begin{abstract}
The aim of the study is to measure the sustainable value added created by companies by spending environmental resources. For this purpose, three enviromental resources were selected: water, energy, and $\mathrm{CO}_{2}$. The amount of consumption of these three environmental resources has been investigated. The study covers the years 2017, 2018 and 2019 of 10 companies listed in the BIST Sustainability Index and operating in the manufacturing sector. With these data, the sustainable added value calculated with the opportunity cost-based approach and the contribution levels of companies to sustainability are revealed. These method and results can be a guide in measuring and understanding the contributions of companies to sustainability.
\end{abstract}

Keywords: Sustainability, Sustainable Value Added, Sustainability performance measurement, Eco-efficiency

JEL Classification: M14, M21, M49

\section{ÇEVRESEL PERFORMANS KAPSAMINDA SÜRDÜRÜLEBILIIR KATMA DEĞERİN ÖLÇÜLMESİ: BIST SÜRDÜRÜLEBILIİRLIK ENDEKSİ ŞiRKETLERINE YÖNELIK BİR UYGULAMA}

\section{Öz}

Çalışmanın amacı, şirketlerin çevresel kaynakları tüketerek yarattığı sürdürülebilir katma değeri ölçmektir. Bu amaçla su, enerji ve $\mathrm{CO}_{2}$ olmak üzere üç çevresel kaynak seçilmiş ve bunların tüketim miktarları araştırılmıştır. Çalışma, BIST Sürdürülebilirlik Endeksinde yer alan ve imalat sektöründe faaliyet gösteren 10 şirketin 2017, 2018 ve 2019 yıllarını kapsamaktadır. Bu verilerden firsat maliyeti temelli yaklaşımla hesaplanan sürdürülebilir katma değer ile şirketlerin sürdürülebilirliğe katkı düzeyleri ortaya konulmuştur. Bu yöntem ve sonuçlar, şirketlerin sürdürülebilirliğe katkılarının ölçülmesinde ve anlaşılmasında yol gösterici olabilir.

\footnotetext{
${ }^{*}$ Makale Geliş Tarihi (Date of Submission): 31.01.2021; Makale Kabul Tarihi (Date of Acceptance): 20.05.2021 ** Abant İzzet Baysal Üniversitesi, Gerede MYO İşletme Bölümü, onurozevin@ibu.edu.tr, (D) https://orcid.org/0000-0002-1347-5027

Atıf (Citation): Özevin, O. (2021). Measuring Sustainable Value Added in the Scope of Environmental Performance: An Application On BIST Sustainability Index Companies. Muhasebe Bilim Dünyası Dergisi, 23(4), 711-732. https://doi.org/10.31460/mbdd.871485.
} 
Anahtar Kelimeler: Sürdürülebilirlik, Sürdürülebilir Katma Değer, Sürdürülebilirlik performans ölçümü, Eko-etkinlik

JEL Sinıflandırması: M14, M21, M49

\section{INTRODUCTION}

In the most general definition of economics, emphasis is placed on the problem of how to meet unlimited human needs with limited resources. For centuries, people have been consuming natural resources first individually and then through companies to meet their needs. Using the resources in the most efficient way to ensure that this consumption is sufficient for future generations is becoming more and more important day by day. The concept of sustainability has become a frequently used concept in many areas of life in recent years. Basically, it reveals the necessity of a consumption planning on the protection of the usage capacity of the resources that cannot be recovered. The fact that the resources are not unlimited, gives more serious signals day by day, bringing with it the need to produce and implement new policies for a sustainable life. For this reason, the principle of efficient use of resources, including environment, society, and industry, becomes as corporate policies.

According to Gilman (1992) sustainability is the functioning of society until an uncertain future without consuming the main resources of the ecosystem. Efficiency in the use of environmental resources, which are regarded as free goods, has come to a very important point along with sustainability targets. Considering that the environmental resources, which are provided very cheap even today, cannot be substituted by human hand, it can be evaluated that they are actually the most expensive production factors. Since businesses are organizations established for profit, it is necessary to create a higher value than the spent in order to gain profit. Here, because the accounting costs of environmental resources are not taken or taken too low into account, their excessive use to increase profits may not cause economic problems. However, ineffective consumption of these resources poses a major problem in terms of sustainability.

Sustainable development can be handled at the country or firm level. Starting with the Brundtland Report (1987) and subsequently which are guaranteed by the governments with many international conventions, is a matter of discussion of how the sustainability contribution targets will catch in the firm level (Atkinson 2000, 236). However, how to measure the contribution to sustainability is another problem. There is a need for generally accepted indicators to measure the contribution to sustainability. Our study aims to measure this impact relatively on the basis of environmental resource use. Thus, companies that contribute positively and negatively to sustainability can be identified, and results can be a warning and guide for the measures to be taken. 
Research on this subject is few due to the limited data on environmental resource usage. Although close to 50 company published sustainability reports in Turkey in 2019 , the contents of the reports are not fully comparable. Accordingly, this study was limited to the period of 2017-2018 and 2019 in a way to include the comsuption of 3 environmental resources out of 10 companies in the research.

The following points can be emphasized for the contribution and originality of the study: First of all, the study shows practically how the level of contribution to sustainability can be measured practically. It presents emprical results based on up-to-date data within the scope of a time series of the last three years regarding sustainable value added creation. Thus, companies' contribution trend to sustainability can be read. It shows comparable results as the entire sample was selected from the manufacturing sector. The study measures the sustainable value added of companies according to the comparative method based on the sector average. In this way, companies that have relatively positive and negative contributions to sustainability have been identified. These methods and results can guide companies in terms of sustainable value added measurement.

The study consists of six parts. After the introduction where the purpose and scope of the study are explained, some previous important studies on the subject have been mentioned in the literature section. Then information on the theoretical background of the subject is presented. The method section is the section where the research data and analysis methods are explained. In the fifth chapter, the findings obtained as a result of analysis and calculations are given in tables and explanations. In the conclusion section, the results obtained based on the findings are presented with discussion and comments.

\section{LITERATURE}

Contribution to sustainability is an issue that highly draws attention, and it is on the agenda due to cyclical popularity. However, the fact that it is difficult to measure because of data limitation so there is limited number of studies in the literature. There are alternative methods suggested in the literature to determine the level of sustainability. Figge and Hahn (2004) classified these methods as: (a) absolute methods; full cost accounting, net value added, green value added and (b) relative methods; productive activity, eco-efficiency. In another classification made by Nikolau et al. (2019), the methods are grouped under three headings; (a) Methods using financial and non-financial indicators; Tyteca, D., 1998; Chvatalová et al., 2011; Salzmann et al., 2005; Atkinson, 2000. (b) Methods focusing on sustainability parameters; environmental-social-economic performance; Delmas and Blass, 2010; corporate social performance; Lindgreen and Swaen, 2010; Wood, 2010; eco-efficiency; Figge and Hahn, 2004; Nikolaou and Matrakoukas, 2016. triple bottom line performance; Elkington, 1997; Alhaddi, 2015; Jackson et al., 2011; Kucukvar and Tatari, 2013. (c) Methods using a variety of measurement 
frameworks (e.g., GRI, Dow Jones or Sustainable Group Index); Kaspereit and Lopatta 2016; Baumgartner and Ebner, 2010; Daub, 2007; Nikolaou, et al., 2019.

Figge et al. (2002) conducted studies relating the Balanced Scorecard method developed by Kaplan and Norton (1996) for corporate sustainability performance measurement with sustainability management. In parallel with this, corporate sustainability; economic, social, and environmental three basic dimensions, performance report card; It is suggested that it can be integrated into four dimensions of financial; customer, internal process, learning and development (White 2005, 38 cited in Özçelik, 2013, 4992). Figge and Hanh later developed this method and presented their methodologies on the measurement of sustainable value added in detail with their similar studies in 2004 and 2005. Again, Figge et al. (2006) used this methodology practically on 65 companies in a large-scale project study and reported the results. This study is basically done by Figge et al. (2006) is based on the method used in the "Sustainable Value of European Industry" project. They investigated the contribution of 65 companies from $16 \mathrm{EU}$ member countries, operating in 18 different sectors, to sustainable value through 7 environmental parameters. Another pioneering study to measure Sustainable Value Added was conducted by Figge and Hahn (2002).

While Atkinson (2000) proposes a framework that evaluates the contributions of firms to sustainable development expressed in financial terms, Ilinitch et al. (1998), using the resources in the conceptual and experimental literature, identified four dimensions of corporate environmental performance; (1) organizational systems; (2) stakeholder relationships; (3) legal compliance and (4) environmental impacts. Using the conceptual model created from these dimensions, they analyzed the main components of publicly available environmental performance indicators. Other literature uses methodologies that combine both financial and non-financial metrics to assess corporate sustainability performance, such as eco-efficiency and the triple bottom line approach; Figge and Hahn, 2004; Nikolaou and Evangelinos, 2012; Nikolaou and Matrakoukas, 2016; Nikolaou, et al., 2019.

Arac1 and Yuksel (2016) used Figge et al. (2006) method in their studies in which they measured the sustainable value added of 16 companies traded in BIST for 2012. In this study, the efficiency of companies is calculated by comparing the national income of the country. It is difficult to interpret the results of the study because it is based on single-year data and does not distinguish between sectors.

Demircioğlu (2014) conducted a theoretical study on the measurement of sustainability by the value added model. Figge and Hanh as the measuring method (2005) examined based on the model, due to lack of scale in Turkey, has mentioned that lack of practical work.

Although there are many methods and theoretical studies on the measurement of sustainability performance, applied studies are very few. Our study aims to contribute to literature with an applied 
study. The original aspect of the study is that it measures sustainable added value over 3-year data and on a sectoral basis.

\section{SUSTAINABILITY}

Although the first debates on sustainability can be traced back to some 18th and 19th century economists such as Malthus and Jevons, the emergence of the concept of "sustainable development" was accompanied by the emergence of environmental concerns in the 20th century (Yeni 2014, 183). Pearce et al. (1990), sustainability is that no future generation is worse than the present generation, that is, the decline in social welfare is prevented over time. The main feature of the concept of sustainability used in different fields is that it includes the human future and the protection of the resources of the area it is used. When viewed from this angle; It is seen as a concept that combines economics, social justice, environmental science and management, business management, politics, and law (Tıraş 2012, 59). These components are intertwined in the same system. The economy provides the needs of society, and the environment provides resources for both society and economy. Companies use economic, environmental, and social resources to produce goods and services that help society meet its needs. Therefore, three components that make up the concept of sustainability come to the force: economy, environment and society. It is this simple relationship that makes companies the driving force and burden of sustainable development at the same time (Hahn 2007, 500).

\subsection{Sustainable Development}

Sustainable development, with its most widespread use, is to meet the needs of today's generations without jeopardizing the ability of future generations to meet their own needs (Sustainability Guide for Companies 2014, 5). Especially the rapid development initiative that started after the second world war led to life-threatening environmental problems. Environmental problems, which were initially ignored in the name of development, gradually moved out of regionalism, and reached a global dimension. With the realization of the irreversible damage to the environment, the "Sustainable Development" model, which is a long-term development model that takes into account the ecosystem that has an effect on all living things and aims at the optimum use of resources, has come to the agenda (Trraş 2012, 58). According to Brundtland Report (1987) in which the concept was used for the first time, sustainable development was defined as follows: "It is the ability of humanity to meet today's needs without jeopardizing the ability to meet the needs of future generations" (Pearce 1993, 7). OECD defines sustainable development as the fulfillment of the needs of today's generations without compromising the needs of future generations (Özmehmet 2008, 11). Sustainable development is a forward-looking concept and emphasizes future performance rather than just current performance, that is, how to be effective in producing goods and services while saving future economic, environmental, and social 
resources. Therefore, sustainable planning of today's resource use is essential for future generations to use the world's resources.

The first discussions on the concept of Sustainable Development came to the agenda during the United Nations Conference held in Stockholm in 1972 as an attempt to find a middle ground between the concerns of developed countries over the environmental consequences of global development and the needs of developing countries for their own economic development. Subsequent developments and gaining the current meaning of the concept have been achieved through activities such as the Burdtland Report (1987), Rio Summit (1992), Kyoto Protocol (1997) Global Reporting Initiative (1997) Rio + 20 Summit, sustainability has been placed on a more institutional basis and increased its importance.

\subsection{Corporate Sustainability}

The understanding of sustainable development corresponds to the expression "corporate sustainability" at the organizational level. Today, it is almost impossible not to come across the concepts of sustainability or sustainable development in a company's website or reports (Mantinel and Ceballaos 2014, 2). Corporate sustainability defined as "development provided without jeopardizing the ability of an institution to meet the needs of its stakeholders and the needs of its future stakeholders" in the simplest way; It can be expressed as reducing the concept of sustainable development to the organizational level (Turhan et al. 2018, 20).

Important problems such as global warming, loss of biodiversity, depletion and pollution of resources, hunger, poverty, unfair income distribution, discrimination, human rights violations and corruption that we are facing today push humanity to seek a new order(Sustainability Guide for Companies 2014, 2) For these reasons, the concepts of corporate sustainability and corporate social responsibility occupy an important place in the agenda of governments, business circles, nongovernmental organizations and academics in recent years. It can be expected that sustainable development will contribute to the achievement of environmental standards, social cohesion, and economic well-being over generations.

The company is an element of the economy, and the economy is an element of society. Therefore, companies have a positive or negative impact on the sustainability of society and the world as a whole (Diesendorf 2000, 5) Environment is an important factor needed by both sides of this system (Turhan et al. 2018, 21). In the BIST Sustainability guide, making the performance evaluation of companies considering only their financial performances is compared to driving only by looking at the rearview mirror (Sustainability Guide for Companies 2014, 2). Today, when social communication and interaction are increasing, the image they present to the society is very important. Therefore, there is a period in which companies are not only found to achieve financial success through the sale of goods and 
services but are also expected to be good corporate citizens who are sensitive to the environment and people (Sustainability Guide for Companies 2014, 2).

Corporate sustainability is the adaptation of economic, environmental, and social factors to the company management by adopting corporate governance principles and managing the risks that may arise from these issues in order to create long-term value in companies (Sustainability Guide for Companies 2014, 2). One of the dynamics of the organizational ecosystem should be sustainability, considering that institutions are established to operate in an infinite life. Therefore, corporate sustainability approach should be adopted, and classical business models should be changed. (Sustainability Guide for Companies 2014, 2).

Day by day, sustainability is rapidly evolving from a preference to a mandatory process for companies. The contributions of sustainability to companies can be listed as follows: increasing brand value, increasing corporate reputation, attracting qualified workforce, decreasing costs in the medium and long term, new business opportunities, easier access to capital, innovative product and service development, company life extension (Sustainability Guide for Companies 2014, 17). Benefits often come from establishing positive and enhanced relationships with authorities and other stakeholders. For example, for companies with a strong record of sustainability performance, permitting processes can be streamlined, thereby reducing the time and investment required to bring new products and services to market. Better access to capital is another advantage, as investors place a high emphasis on environmental and social performance and prefer companies with appropriate records (Epistein and Roy 2001, 598). Considering these advantages, the sustainability strategy can be expected to contribute to the financial performance of companies. At the enterprise level, it is seen that corporate sustainability is associated with competition, innovation, and marketing components at a high level. From this point of view, any company can gain a competitive advantage through corporate sustainability (Diaz-Balteiro et al., 2011 as cited in Öztel et al. 2012).

\subsection{Sustainability Reporting}

The need for International Integrated reporting has arisen as a result of the understanding that companies can no longer be valued only by financial performance, but also that social and environmental performance is valued by stakeholders. This situation made it important to report non-financial activity results together with financial reporting. Non-financial reports include more comprehensive and detailed information than the financial information of companies such as corporate governance compliance statement, corporate social responsibility (CSR) report and sustainability reports (http://entegreraporlamatr.org/tr/hakkimizda/biz-kimiz.aspx).

A sustainability report is a report containing information about the economic, environmental, and social impacts caused by its daily activities by a company or organization. A sustainability report also 
presents the organization's values and governance model, showing the operating results and its contribution to the sustainable economy. https://www.globalreporting.org/information/sustainabilityreporting/Pages/default.aspx

Since investors now take sustainability factors into account in their investment decision, capital market regulators and stock exchanges have carefully focused on the issue; companies have begun to take various initiatives to spread the awareness of sustainability among investors and society (Sustainability Guide for Companies 2014, 2). In addition to the physical cost-reducing effects, sustainability actions can also gain the positive response of the customer with the positive image they give to the society due to their social benefits. While $70 \%$ of publicly traded companies worldwide report in the field of corporate responsibility, it is seen that $95 \%$ of multinational companies included in the Global Fortune 250 list and located in 34 different countries publish their activities and results in employee rights, environment, and stakeholder relations together with their annual financial reports (Sustainability Guide for Companies 2014, 5).

Borsa İstanbul has created the "BIST Sustainability Index" based on the environmental, social, and corporate governance performance of companies under the code of XUSRD since 4 November 2014. Accordingly, EIRIS evaluates Borsa İstanbul companies according to international sustainability criteria, and only "publicly available" information is used in the valuations (Sustainability Guide for Companies 2014, 2).

\subsection{Measuring Sustainable Value Added}

Many different parameters have been developed to measure sustainability. These are economical; cost-efficiency, RandD expenses, profit, environmental; CO2 emission, energy, resource consumption and social; it covers broad areas such as security, health, trade union rights and corporate accountability (OECD;2008, 7). The most basic way to measure the contribution of companies to sustainability is to subtract the total cost from the total benefit. For this, all internal and external costs must be determined. This can be calculated using the full cost accounting method. Following this approach, if the total benefits created by the company exceed the sum of internal and external costs, sustainability is contributed. The result can be called "net value added" by Huizing and Dekker (1992), or "Green Value added" by Atkinson (2000), and (Figge and Hanh 2004, 173).

Sustainable Value Added takes into account both efficiency and absolute level of resource use. Sustainable Value added is the extra value created when the general level of environmental and social impacts is kept constant (Figge and Hanh 2004, 174). The financial performance of a company in terms of value added requires taking into account the external environmental costs resulting from its activities. Therefore, environmental, and social uses are monetized with these concepts (Figge and Hanh 2004, 175). Absolute approaches such as cost accounting are difficult to monetize environmental and social 
costs, so their usefulness is controversial. Relative practices express organizational contributions to sustainability as a unit benefit per environmental or social impact and can therefore avoid some of the problems mentioned above. The most frequently used of the relative methods is eco-efficiency.

As defined by the World Sustainable Development Business Council (WBCSD), "eco-efficiency enables the provision of competitively priced goods and services that meet human needs and bring quality of life while gradually reducing life-cycle ecological impacts and resource intensity. In short, it is about creating more value with less effect (Eco-efficiency Learning Module 2006, 3). EEA (European Economic Area) defines eco-efficiency as an approach that takes into account the economic activities carried out to meet human needs with the carrying capacity of the world and the use of the environment of future generations (EEA 1999, 35) as cited in (Sefer and Villi 2013, 400).

Eco-efficiency is based on the principle of using less natural resources and energy and less waste generation for the same amount of production, using high efficiency production technologies and methods. With this feature, it addresses not only environmental concerns, but also many different areas such as "protection of natural resources", "industrial efficiency" and "economic development". In short, eco-efficiency means providing both environmental and economic benefits by increasing productivity in production (https://www.ekoverimlilik.org/?cat=4).

Eco-efficiency tries to measure the economic activity (national income) of countries and the environmental performance of companies in their product or service production processes. The basic philosophy of eco-efficiency; while trying to create more value to increase efficiency, it is also minimizing the total emission volume by reducing energy consumption and material use. Eco-efficiency can calculate as dividing the product or service value to environmental impact.

In order to increase human welfare in a sustainable way, productivity should be increased, or at least protected, together with the increase in the capital stock. From an economic point of view, the issue of sustainability has therefore been approached within the framework of efficiency in resource allocation, the effect of limited resources on growth, technological progress and the substitution of resources, namely capital types (Yeni 2014, 187).

Although there are many different definitions and debates about the concept of sustainability, it is the generally accepted view that the most appropriate way to ensure the welfare of future generations is to ensure that the next generation has access to a capital stock at least as large as today (Yeni 2014,198). There are two poles in the sustainability framework for the substitution of capital types. The first is "poor sustainability" and states that capital should be prevented from declining over time. The poor sustainability approach is based on the basic assumption that man-made capital can replace natural capital. In other words, what matters is the "overall" portfolio that is inherited to the future. Sustainability will be achieved as long as the decreasing capital can be substituted (Atkinson 2000, 236). The view 
that all types of capital can be fully substituted with each other is the basis of the weak sustainability approach (Figge and Hanh 2004,175). However, an important point of criticism is that natural capital cannot be substituted for man-made capital.

On the other hand, "strong sustainability" emphasizes the conservation of natural resources to manage resources more discreetly over time. This approach suggests that natural capital is structurally different from other types of capital. The underlying rationale is that natural resources, which play a critical role in the maintenance of life, are not substitutable (Atkinson 2000, 236). Irreversibility of natural capital is not possible or limited in some cases (Yeni 2014, 199). Once some forms of natural capital are destroyed, they cannot be regenerated. Therefore, strong sustainability approach argues that there is no complete substitution between capital types, at least some types of capital cannot be substituted (Figge and Hanh 2004, 175).

In this study, based on eco-efficiency in the measurement of sustainable value added, based on the method used in the Advance Project by Figge et al. (2006). This method is based on opportunity cost, such as economic value added. Considering the potential use of the same resources by different enterprises in different efficiency in the absolute measurement approach, it can be said that the value created is not net value added but "absolute sustainable value added". The exact substitution between resource types is uncertain because the external effects that will occur as a result of the activities cannot always be measured precisely or the innovations that may occur in the environmental or social field cannot be predicted (Rees 1999, 49. Transmitted; Demircioğlu 2014, 41).

For all these reasons, the "relative sustainable value added" approach may be preferred in measuring sustainable value added. "Relative sustainable value added " measures whether a business contributes to sustainable development compared to another business or national income with the changes in its economic, social, and environmental performance in a certain period. If the enterprise uses its economic, social, and environmental resources more efficiently than another enterprise, it creates relative sustainable value added (Figge and Hahn, 2005: 48).

The sustainable value added approach has adopted the principle that businesses will create value by using their existing resources more efficiently than other businesses. In this context, the sustainable value added of enterprises can be calculated based on the "opportunity cost" approach (Barkemeyer et al. 2009, 291).

A model based on answering the following questions is followed in the calculation of sustainable value added:

1. What is the amount of resources used by the business?

2. How much value does the business create with these resources? 
3. How much value does the peer business create with this resource?

4. What are the sources of the business that create and do not create value?

5. How much sustainable value has the business created? (Figge et al. 2006, 18).

The answers to these questions give us the sustainable value created by a company, that is, its contribution to sustainability.

\section{METHODOLOGY}

In this study applied the method that used in the study titled "Sustainable Value of European IndustryA Value-Based Analysis of the Environmental Performance of European Manufacturing Companies" by Figge et al. (2006) which is based on the calculation of sustainable value added created by the use of resources within the scope of environmental performance of 65 companies operating in the European Union.

The stages of the model to be used in our study can be summarized as follows.

STAGE 1: Firms' environmental resource consumption amount (RCA) is determined. Environmental resources in the study; It consists of three headings: water, energy, and greenhouse gas emissions. The annual usage of environmental resources has been obtained from the sustainability reports published by the companies.

STAGE 2: Gross Value Added (GVA) is calculated from the financial data of the companies. Gross value added is a value expressing the contribution of the company to GNP (Figge 2006, 19) This value is not a data explained in the financial statements and can be calculated as follows (Figge 2006, 35)

GVA = Operating Profit + Depreciation and Amortization Expenses + Personnel Expenses

This value can also be calculated by adding personnel expenses to EBIT.

STAGE 3: Resource consumption efficiency per unit (RCE) is calculated. This calculation is found by dividing the company's gross value added the resource utilization rate.

$$
\mathrm{RCE}=\mathrm{GVA} / \mathrm{RCA}
$$

STAGE 4: The company value contribution (VC) is calculated by comparing the sector's average RCE (opportunity cost) with the company's RCE. Opportunity cost is taken as the resource use efficiency of the industry average. If the company has an above average resource utilization efficiency, it means that the company creates a value contribution. 
Opportunity cost for each resource of the enterprise is calculated by multiplying the resource usage efficiency of the precedent with the resource usage amount of the enterprise. Between the return of the business and the opportunity cost, it will contribute to the sustainability of the business in monetary terms. Thus, the efficiency of environmental and social resources, which are difficult to measure in monetary terms, and the sustainable value added of the enterprise will be calculated (Aracı and Yüksel 2016, 789).

Company's Source of Resource Consumed $=$ RCA x Company RCE

Opportunity Cost $=$ RCA x Sector RCE

$\mathrm{VC}=($ RCA $x$ Company RCE $)-($ RCA $x$ Sector RCE $)$

If the value contribution gets a positive value, it means that the company has created a return above the industry average with the resources it uses. Therefore, it means that the company makes a positive contribution to sustainability.

STAGE 5: The final sustainable value is calculated by taking the total value contribution calculated for all analyzed environmental consumption. Sustainable Value Added takes into account both efficiency and absolute level (effectiveness) of resource use. Sustainable Value Added is the extra value created when the overall level of environmental and social impacts is kept constant (Figge and Hanh 2004, 174).

Sustainable Value $=\mathrm{SV}_{\text {gas }}+\mathrm{SV}_{\text {Energy }}+\mathrm{SV}_{\text {water }}+\mathrm{SV}_{\text {waste }}+\mathrm{SV}_{\text {other }}$

6. STAGE: The value created by the company as a result of the use of resources is divided by the opportunity cost to calculate the return cost ratio (RCR). If the return of the business is more than the opportunity cost, the business makes a positive contribution to sustainability. Otherwise, it means that no sustainable value has been created with business activities. The sustainable value added created by the enterprise can also be calculated proportionally at this stage. This calculation will be as follows (Figge and Hahn 2006, 23):

\section{RCR = Company Generated Return / Opportunity Cost}

Since sustainable value added is based on opportunity cost, there is a need for comparison. A benchmark may also be a similar business operating in the same sector, sector average or GDP (Barkemeyer et al. 2009, 13-14)

Sustainable value expresses whether the value created by the company exceeds the opportunity cost of capital use (Figge and Hahn 2005, 51). Positive sustainable value added shows that while maintaining the overall consumption of each resource used at the level of the previous period, the enterprise is successful in creating additional value compared to the precedent (Figge and Hahn 2004, 182). 


\subsection{Data Set}

BIST Sustainability Index lists 44 companies in 2017, 50 companies in 2018 and 56 companies in 2019. As of 2019, companies in the manufacturing sector listed in the BIST Sustainability index have been the subject of the study. Although there are 23 companies that meet these criteria, the 10 companies whose published sustainability report and whose environmental consumtion data were exist completely in this report were selected as the sample. The reason for choosing the manufacturing sector is the industries that use environmental resources in production, and the reason for choosing companies from the same sector is to be able to make comparative analysis. The data used in the study were obtained from the sustainability reports and financial reports published by the companies.

\subsection{Limitations}

In the study, only 10 companies from the manufacturing industry companies included in the BIST Sustainability index were able to access continuous and complete data within the date range. For this reason, the study is limited to the 2017, 2018 and 2019 operating periods of these 10 companies, whose sustainability data can be accessed.

Table 1. Companies Examined Within the Scope of the Study

\begin{tabular}{|l|l|l|}
\hline \multicolumn{1}{|c|}{ BIST code } & \multicolumn{1}{c|}{ Company } & Industry \\
\hline AEFES & ANADOLU EFES BİRACILIK VE MALT SANAYİI A.Ş. & MANUFACTURING \\
\hline ARÇELIK & ARÇELIK A.Ş. & MANUFACTURING \\
\hline AYGAZ & AYGAZ A.Ş. & MANUFACTURING \\
\hline ÇIMSA & ÇIMSA ÇIMENTO SANAYİ VE TİCARET A.Ş. & MANUFACTURING \\
\hline FROTO & FORD OTOMOTIV SANAYİ A.Ş. & MANUFACTURING \\
\hline KEREVİTAŞ & KEREVİTAŞ GIDA SANAYİ VE TİCARET A.Ş. & MANUFACTURING \\
\hline ŞIŞE & TÜRKIYYE ŞIŞE VE CAM FAB. A.Ş. & MANUFACTURING \\
\hline OTKAR & OTOKAR OTOMOTIV VE SAVUNMA SANAYİ A.Ş. & MANUFACTURING \\
\hline ÜLKER & ÜLKER BİSKÜVİ SANAYİ A.Ş. & MANUFACTURING \\
\hline TOFAŞ & TOFAŞ TÜRK OTOMOBİL FABRIKASI A.Ş. & MANUFACTURING \\
\hline
\end{tabular}

In addition, it is limited to the data common to the sustainability reports of all companies subject to the study on environmental resource use. These three items are greenhouse gas emission, water withdrawal and energy consumption. Other environmental consumption and waste have been excluded due to insufficient data. Although all companies publish their sustainability reports according to the GRI index, the explanation way for other environmental performance data differs. Some companies explain savings / reduction values instead of total consumption data, while some companies report values 
according to the base year. Other environmental resource uses such as other gas emissions, waste management, environmental investments are excluded due to the inaccessibility of all companies' data.

\section{FINDINGS}

As a result of the study, the sustainable values added of 10 companies operating in the BIST manufacturing sector for 2017, 2018 and 2019 were calculated. Results are presented below in tables and graphs.

\subsection{Contribution to Sustainability (Return-Cost Ratio)}

The return cost ratio (RCR) calculated by dividing the value created by the company's environmental resource consumption by the opportunity cost indicates the rate of contribution of the enterprise to sustainability. If the return of the business is more than the opportunity cost, the business makes a positive contribution to sustainability. Otherwise, it means that no sustainable value has been created with business activities. Even if the enterprise has created a positive value added, unless this value is above the opportunity cost, a positive value is not provided in economic terms. In Table 2, the returncost ratios of the companies subject to study, calculated on the basis of years are given. RCR shows whether the company uses resources efficiently according to the comparison. Since the precedent taken in our study is the sector average, RCR shows the efficiency compared to the average.

Table 2. Return-Cost Ratios

\begin{tabular}{|c|l|c|c|c|}
\hline & & $\mathbf{2 0 1 7}$ & $\mathbf{2 0 1 8}$ & $\mathbf{2 0 1 9}$ \\
\hline 1 & AEFES & 1,91 & 1,89 & 2,08 \\
\hline 2 & ARÇELIK & 10,79 & 19,22 & 21,07 \\
\hline 3 & AYGAZ & 8,67 & 1,54 & 15,54 \\
\hline 4 & ÇİMSA & 0,67 & 0,76 & 0,62 \\
\hline 5 & FORD & 5,32 & 7,56 & 4,87 \\
\hline 9 & KEREVITAŞ & 1,55 & 1,72 & 1,56 \\
\hline 6 & ŞİŞE & 0,18 & 0,19 & 0,18 \\
\hline 7 & OTOKAR & 8,74 & 11,68 & 13,98 \\
\hline 8 & ÜLKER & 2,38 & 3,33 & 4,07 \\
\hline 10 & TOFAŞ & 5,24 & 7,63 & 8,55 \\
\hline
\end{tabular}

According to Table 2, the company with the highest RCR was Arçelik by a large margin. Arçelik has been using resources approximately 20 times more efficiently than the average in the last two years. Otokar follows the Arçelik company with an average of 12 times higher efficiency. It means that 
companies with a RCR value below "1" in Table 2 exhibit negative efficiency. In other words, if the opportunity cost is 1 , companies with a ratio of less than 1 have negative environmental performance compared to the equivalent. It is seen that Çimsa uses approximately $30 \%$ inefficient resources in three years compared to its peers. Likewise, the bottle glass company uses $80 \%$ of environmental resources inefficiently compared to the average. It is striking that these two companies, which seem inefficient according to the rate of return, are involved in heavy industry production compared to others.

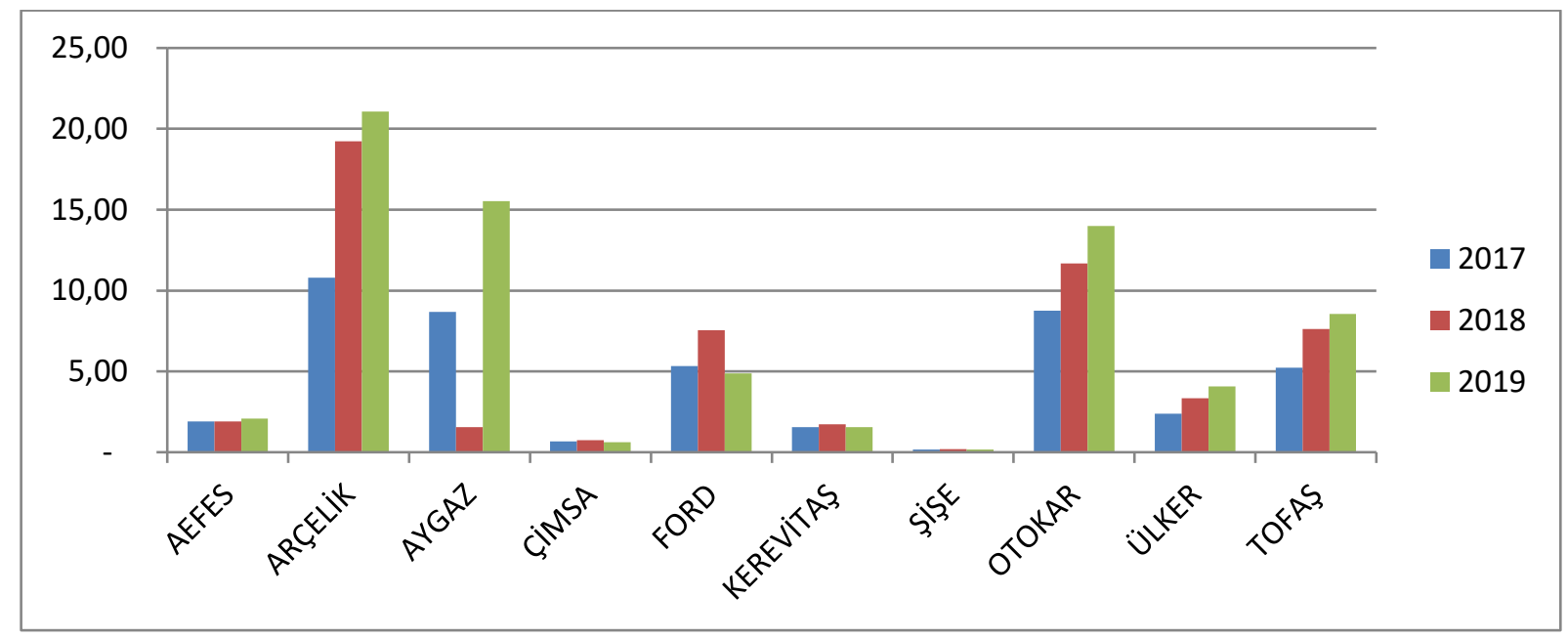

\section{Figure 1. Return-Cost Ratio}

Figure 1 shows the three-year return-cost ratio trends of companies. Accordingly, a positive course is observed over the years. Features The steady development in Arçelik, Otokar and Tofaş companies stands out.

\subsection{Sustainable Value Added}

Sustainable Value Added takes into account both efficiency and absolute level (effectiveness) of resource use. Sustainable Value Added is the extra value created when the general level of environmental and social impacts is kept constant (Figge and Hanh 2004, 174). In this section, the monetary value of the sustainable contribution created by companies is calculated.

Table 3 shows the sustainable value added created by the companies in terms of consumption of the 3 environmental resources subject to the study, in other words, the consumption efficiency of these environmental resources.

Accordingly, Anadolu Efes company made a positive contribution to sustainability in 2017 and 2018. In other words, while the company created a more sustainable value of 1.69 billion TL in 2017 and 2.35 billion TL in 2018, this figure decreased to 514 million TL in 2019. It is noteworthy that more than 4 times the decrease that occurs in a year. 
Table 3. Sustainable Value Added

\begin{tabular}{|l|c|c|c|}
\hline (thousand) & 2017 & 2018 & 2019 \\
\hline AEFES & $1.688 .915,34$ & $2.345 .039,17$ & $514.394,67$ \\
\hline ARÇELIK & $4.105 .012,30$ & $5.927 .152,85$ & $4.178 .132,62$ \\
\hline AYGAZ & $374.424,44$ & $81.400,76$ & $385.159,53$ \\
\hline Çi̇SA & $-217.925,16$ & $-154.355,05$ & $-277.644,97$ \\
\hline FORD & $2.586 .503,34$ & $3.546 .398,73$ & $2.528 .234,69$ \\
\hline KEREVITAŞ & $586.533,61$ & $737.366,48$ & $460.089,35$ \\
\hline ŞİŞE & $-11.583 .141,92$ & $-15.638 .811,67$ & $-19.226 .628,38$ \\
\hline OTOKAR & $434.450,98$ & $479.760,89$ & $433.501,14$ \\
\hline ÜLKER & $454.813,38$ & $687.268,47$ & $439.883,93$ \\
\hline TOFAŞ & $302.121,41$ & $613.392,87$ & $396.292,20$ \\
\hline
\end{tabular}

Arçelik company has made a positive contribution to sustainability in the last three years. The sustainable value created by this company was calculated as 4.1 billion TL in 2017, 5.9 billion TL in 2018 and 4.1 billion TL in 2019. It is the company that creates the biggest sustainable value among the companies subject to the research.

The sustainable value of Aygaz company was 374 million TL in 2017, 81 million TL in 2018 and 385 million TL in 2019. Despite having low levels of value added among the other companies in the table, it created positive value added in all three years.

The Çimsa company has created negative sustainable value in the last 3 years. The company's contribution to sustainability is -217 million TL in 2017, -154 million TL in 2018 and -277 million TL in 2019. This shows that the company uses environmental resources less efficiently than average.

Looking environmental performance of the Ford company for the last three years, it is seen that the company has made a positive contribution to sustainability. The sustainable value created by the company was 2.59 billion TL in 2017, 3.55 billion TL in 2018 and 2.53 billion TL in 2019. It can be said that the company creates a sustainable value above the industry average.

Considering the sustainable value creation capacity of Kerevitaş company, it is seen that it made a positive contribution of 586 million TL in 2017, 737 million TL in 2018 and 460 million TL in 2019.

Şişecam company is the company that creates the highest negative sustainable value in the study. The contribution of the company to sustainable value was calculated as -11.5 billion TL in 2017, -15.6 billion TL in 2018 and -19.2 billion TL in 2019. From 2017 to 2019, the negative impact on sustainable value has increased by almost $75 \%$. 
Otokar's sustainable value contribution was calculated as 433 million TL in 2019. Having made a positive contribution in the last three years, the sustainable value of the company was 434 million TL in 2017 and 433 million TL in 2018.

Ülker company has created positive and sustainable value according to the data of the last three years. The contribution of the company to sustainability is 454 million TL in 2017, 687 million TL in 2018 and 439 million TL in 2019.

Tofaş's contribution to sustainability was calculated as 302 million TL in 2017, 602 million TL in 2018 and 396 million TL in 2019. Although the efficiency increase achieved in 2018 was not maintained in 2019, it seems that the company made a positive contribution to sustainability.

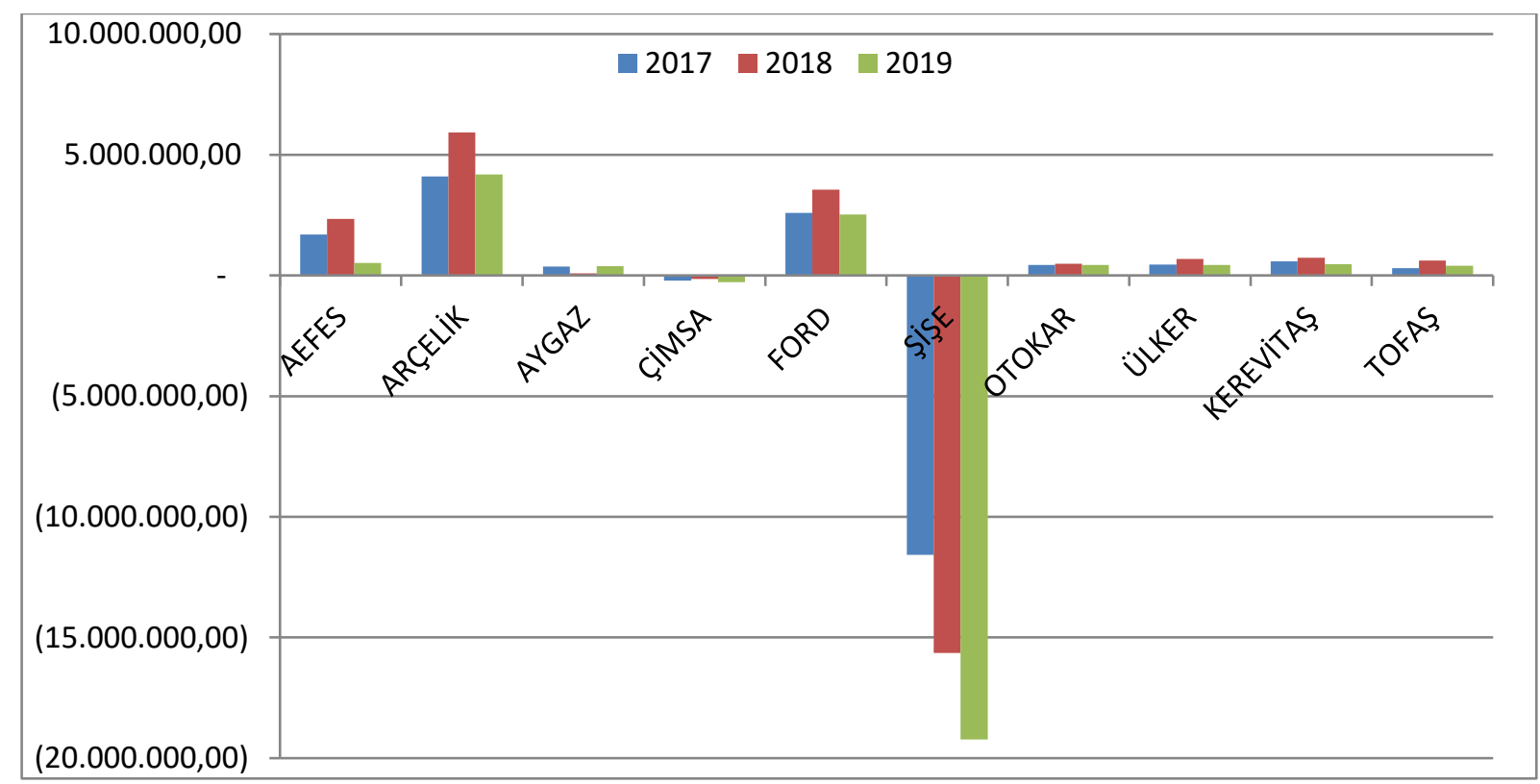

\section{Figure 2. Sustainable Value Added}

Looking at Figure 2, it is observed that the sustainable contributions of companies, which were increased in 2018, started to decrease in 2019, the reasons for the increase in 2018 and the decrease in 2019 may also be an issue that should be investigated. Çimsa and Şişecam companies among the companies subject to the research for the years 2017-2018 and 2019, while creating negative sustainable value, all other companies seem to have made positive sustainable contributions.

\section{CONCLUSION}

In the study, the sustainable value added of 10 manufacturing companies listed in the BIST sustainability index was calculated according to the opportunity cost-based sustainable value added approach. The study based on the model Figge et al. (2006) calculated the eco-efficiency in consumption 
of three environmental resources (energy, water, and greenhouse gas emissions) and the sustainable value added created in a three-year time series. The sustainable value added created by the companies involved in the study was calculated in monetary terms and the resource consumption efficiency was given in proportion according to the precedent. As a result, companies that create positive value added and negative value added have been identified. All data are taken from sustainability reports and financial reports published by companies. The study shows that companies' contributions to sustainability can be calculated in a meaningful way using publicly available data. The opportunity costbased sustainable value approach used in the study envisages the use of opportunity cost calculation, which is used only in the evaluation of monetary capital, within environmental resources. Therefore, it emphasizes the importance of not only capital-focused growth but also sustainable value-added growth for companies.

The study is limited to the sustainable value added analyzes of 10 manufacturing industry companies listed in the BIST sustainability index due to data scarcity. In this context, it presents detailed results regarding the sustainable value added and eco-activities created by the companies researched. The environmental performance of the companies involved in the study over a three-year period between 2017 and 2019 has been analyzed, allowing to distinguish between companies that ultimately improve their sustainability performance and companies whose performance has deteriorated over the years. The results of the study show that some companies use environmental resources up to 20 times more efficiently than their peers, while others use up to $80 \%$ less efficiently than the average. The reasons for these results can be investigated at company scale with detailed analysis.

The results of the sustainable value analysis can be used by company managers, investors, and other different stakeholders. It also provides useful data for regulatory and supervisory organizations within the scope of environmental performance monitoring. The results of the future performance scenario can be used as early warning signals especially for relevant environmental sources.

In future studies, more meaningful results can be achieved by expanding the sample as more companies publish sustainability reports. In addition, similar studies can be carried out for different sectors and the results can be compared and the sustainability performance can be determined on a sectoral basis. On the other hand, studies can be expanded to include the use of economic and social resources as well as environmental resources. 


\section{YAZARIN BEYANI}

Bu çalışmada, Araştırma ve Yayın Etiğine uyulmuştur, çıkar çatışması bulunmamaktadır ve finansal destek alınmamıştır.

\section{AUTHOR'S DECLARATION}

This paper complies with Research and Publication Ethics, has no conflict of interest to declare, and has received no financial support.

\section{REFERENCES}

Alhaddi, H. 2015. "Triple Bottom Line and Sustainability: A Literature Review", Business and Management Studies, 1(2), 6-10.

Aracı, H., and Yüksel, F. 2016. "Sürdürülebilirlik Performansının Ölçülmesi: BİST Sürdürülebilirlik Endeksindeki İşletmelerin Sürdürülebilir Katma Değerinin Hesaplanması", Uluslararası Yönetim İktisat ve İşletme Dergisi, 30, 786-801.

Atkinson, G. 2000. "Measuring Corporate Sustainability", Journal of Environmental Planning and management, 43(2), 235-252.

Baumgartner, R. J., and Ebner, D. 2010. "Corporate Sustainability Strategies: Sustainability Profiles and Maturity Levels", Sustainable Development, 18(2), 76-89.

Brundtland, G. H., Khalid, M., Agnelli, S., Al-Athel, S. and Chidzero, B. J. N. Y. 1987. Our Common Future. New York, 8.

Daub, C. H. 2007. “Assessing The Quality of Sustainability Reporting: An Alternative Methodological Approach", Journal of Cleaner Production, 15(1), 75-85.

Delmas, M., and Blass, V. D. 2010. "Measuring Corporate Environmental Performance: The Trade-Offs of Sustainability Ratings", Business Strategy and the Environment, 19(4), 245-260.

Demircioğlu Sarı, A. 2014. "Sürdürülebilir Katma Değer Yaklaşımı İle Sürdürülebilirlik Ölçümü”, Uluslararas1 Akademik Yönetim Bilimleri Dergisi, 1(1), 38-51.

Diesendorf, M. 2000. "Sustainability and Sustainable Development", Sustainability: The Corporate Challenge of the 21st Century, 2, 19-37.

Elkington, J. 1997. “The Triple Bottom Line. Environmental Management: Readings and cases”, 2. 
Figge F., Barkemeyer R., Hahn T., Hansberg B., Daverio C., Savia R., Persson M., König J., Brunezel B., Wilhelm A. and Mauritz C. 2006. "Sustainable Value of European Industry, A Value Based analysis of The Enviromental Performance European Manufacturing Companies", The Advanced Project.

Figge, F. and Hahn, T. 2004. "Sustainable Value Added-Measuring Corporate Contributions to Sustainability Beyond Eco-Efficiency”, Ecological Economics, 48(2), 173-187.

Figge, F. and Hahn, T. 2005. "The Cost of Sustainability Capital and The Creation of Sustainable Value by Companies", Journal of Industrial Ecology, 9(4), 47-58.

Figge, F., Hahn, T., Schaltegger, S. and Wagner, M. 2002. "The Sustainability Balanced ScorecardLinking Sustainability Management to Business Strategy", Business Strategy and The Environment, 11(5), 269-284.

Figge, F., Hahn, T., Schaltegger, S., and Wagner, M. 2002. "The Sustainability Balanced ScorecardLinking Sustainability Management to Business Strategy", Business Strategy and The Environment, 11(5), 269-284.

Gilman, R. 1992. "Sustainability, UIA / AIA Call for Sustainable Community Solutions", http://www.context.org, Access Date: 25.04.2020

Hahn, T., Figge F. and Barkemeyer R. 2007. "Sustainable Value Creation Among Companies in The Manufacturing Sector", International Journal of Environmental Technology and Management, 7(5/6),496-512.

Ilinitch, A. Y., Soderstrom, N. S., and Thomas, T. E. 1998. "Measuring Corporate Environmental Performance", Journal of Accounting and Public Policy, 17(4-5), 383-408.

Jackson, A., Boswell, K., and Davis, D. 2011. "Sustainability And Triple Bottom Line Reporting-What İs İt All About", International Journal of Business, Humanities and Technology, 1(3), 55-59.

Kaspereit, T. and Lopatta, K. 2016. "The Value Relevance of Sam's Corporate Sustainability Ranking and GRI Sustainability Reporting in the European Stock Markets", Business Ethics: A european review, 25(1), 1-24.

Kucukvar, M., and Tatari, O. 2013. "Towards A Triple Bottom-Line Sustainability Assessment of the US Construction Industry”, The International Journal of Life Cycle Assessment, 18(5), 958-972.

Lindgreen, A., and Swaen, V. 2010. "Corporate Social Responsibility", International journal of management reviews, 12(1), 1-7. 
Nikolaou, I. E., and Matrakoukas, S. I. 2016. "A Framework to Measure Eco-Efficiency Performance of Firms Through EMAS Reports", Sustainable Production and Consumption, 8, 32-44.

Nikolaou, I., \& Evangelinos, K. 2012. "Financial and non-financial environmental information: significant factors for corporate environmental performance measuring", International Journal of Managerial and Financial Accounting, 4(1), 61-77.

Nikolaou, I. E., Tsalis, T. A., and Evangelinos, K. I. 2019. "A Framework to Measure Corporate Sustainability Performance: A Strong Sustainability-based View of Firm", Sustainable Production and Consumption, 18, 1-18.

OECD Sustainable Development Studies Measuring Sustainable Production. 2008. OECD Publishing. https://www.oecd.org/greengrowth/measuringsustainableproduction.htm

Özçelik, F. 2013. "Sürdürülebilirlik Performans Karnesi”. Journal of Yaşar University, 8(30), 49855008.

Özmehmet, E. 2008. "Dünyada ve Tükiye Sürdürülebilir Kalkinma Yaklaşımları”, Journal of Yaşar University, 3(12), 1853-1876.

Öztel, A., Köse, M. S., and Aytekin, İ. 2012. "Kurumsal Sürdürülebilirlik Performansının Ölçümü İçin Çok Kriterli Bir Çerçeve: Henkel Örneği”, Journal of History Culture and Art Research, 1(4), 32-44.

Pearce, D. W., Barbier, E. B., and Markandya, A. 1990. Sustainable Development: Economics and Environment in the Third World. Edward Elgar, Aldershot.

Salzmann, O., Ionescu-Somers, A., and Steger, U. 2005. "The business case for corporate sustainability: literature review and research options", European Management Journal, 23(1), 27-36.

Şirketler için Sürdürülebilirlik Rehberi, Borsa İstanbul, 2014, https://www.borsaistanbul.com/data/kilavuzlar/surdurulebilirlik-rehberi.pdf

Tiraş, H. H. 2012. "Sürdürülebilir Kalkinma ve Çevre: Teorik Bir İnceleme”. Kahramanmaraş Sütçü İmam Üniversitesi İktisadi ve İdari Bilimler Fakültesi Dergisi, 2(2), 57-73.

Turhan, G. D., Özen, T., and Albayrak, R. S. 2018. "Kurumsal Sürdürülebilirlik Kavramı, Stratejik Önemi Ve Sürdürülebilirlik Performansı Ölçümü”, Ege Stratejik Araştırmalar Dergisi, 9(1), 17-37.

Tyteca, D. 1998. "Sustainability Indicators at The Firm Level: Pollution and Resource Efficiency as a Necessary Condition Toward Sustainability”, Journal of Industrial Ecology, 2(4), 61-77.

Wood, D. J. 2010. "Measuring Corporate Social Performance: A Review", International Journal of Management Reviews, 12(1), 50-84.

www.ekoverimlilik.org/?cat=4 (Erişim tarihi: 11.12 .2020$)$ 
www.entegreraporlamatr.org/tr/hakkimizda/biz-kimiz.aspx (Erişim tarihi: 11.12.2020)

www.globalreporting.org/information/sustainability-reporting/Pages/default.aspx, (Erişim tarihi: 11.12.2020)

www.wbcsd.org/Projects/Education/Resources/Eco-efficiency-Learning-Module, (Erişim tarihi: 11.12.2020)

Yeni, O. 2014. "Sürdürülebilirlik ve Sürdürülebilir Kalkınma: Bir Yazın Taraması”, Gazi Universitesi Iktisadi ve Idari Bilimler Fakultesi Dergisi, 16(3), 181-208. 